Marquette University

e-Publications@Marquette

3-23-1998

\title{
Synthesis, Molecular Structure, and Reactivity of Dinuclear Copper(II) Complexes with Carboxylate-Rich Coordination Environments
}

\author{
Richard C. Holz \\ Marquette University, richard.holz@marquette.edu \\ John M. Bradshaw \\ Utah State University \\ Brian Bennett \\ Marquette University, brian.bennett@marquette.edu
}

Follow this and additional works at: https://epublications.marquette.edu/physics_fac

Part of the Biological and Chemical Physics Commons

\section{Recommended Citation}

Holz, Richard C.; Bradshaw, John M.; and Bennett, Brian, "Synthesis, Molecular Structure, and Reactivity of Dinuclear Copper(II) Complexes with Carboxylate-Rich Coordination Environments" (1998). Physics Faculty Research and Publications. 57.

https://epublications.marquette.edu/physics_fac/57 
Marquette University

e-Publications@Marquette

\section{Physics Faculty Research and Publications/College of Arts and Sciences}

This paper is NOT THE PUBLISHED VERSION; but the author's final, peer-reviewed manuscript. The published version may be accessed by following the link in the citation below.

Inorganic Chemistry, Vol. 37, No. 6 (1 March 1998): 1219-1225. DOI. This article is (C) American Chemical Society Publications and permission has been granted for this version to appear in ePublications@Marquette. American Chemical Society Publications does not grant permission for this article to be further copied/distributed or hosted elsewhere without the express permission from American Chemical Society Publications.

\section{Synthesis, Molecular Structure, and Reactivity of Dinuclear Copper(II) Complexes with Carboxylate-Rich Coordination Environments}

Richard C. Holz

Department of Chemistry and Biochemistry, Utah State University, Logan, Utah John M. Bradshaw

Department of Chemistry and Biochemistry, Utah State University, Logan, Utah Brian Bennett

Department of Chemistry and Biochemistry, Utah State University, Logan, Utah

\section{SUBJECTS:}

Peptides and proteins, Ligands, Pyridines, lons, Oxygen 


\section{Abstract}

The dinucleating ligand $N, N^{\prime}$-(2-hydroxy-5-methyl-1,3-xylylene)bis ( $N$-(carboxymethyl)glycine) $\left(\mathrm{CH}_{3} \mathrm{HXTA}\right)$ has been used to synthesize the dinuclear $\mathrm{Cu}(\mathrm{II})$ bis(pyridine) complex $\mathrm{Na}\left[\mathrm{Cu}_{2}\left(\mathrm{CH}_{3} \mathrm{HXTA}\right)(\mathrm{Py})_{2}\right] \cdot 1.5$ (1,4-dioxane) $(\mathrm{Na}(1))$ : triclinic space group PI $\left(a=12.550\right.$ (3) $\AA, b=13.413$ (3) $\AA, c=13.540(4) \AA, \alpha=117.12(2)^{\circ}, \beta=104.70(2)^{\circ}$, and $\left.\gamma=92.13(2)^{\circ}\right)$. The structure shows two distinct distorted square pyramidal $\mathrm{Cu}(\mathrm{II})$ centers with each $\mathrm{Cu}(\mathrm{II})$ ion bound by two carboxylate oxygen atoms, one amine nitrogen atom, a phenolate oxygen atom, and one pyridine nitrogen atom. The $\mathrm{Cu}-\mathrm{-Cu}$ separation is $3.531 \AA$, and the $\mathrm{Cu} 1-\mathrm{O} 1-\mathrm{Cu} 2$ angle is $123.7^{\circ}$. The phenyl ring of the $\mathrm{CH}_{3} \mathrm{HXTA}$ ligand is twisted relative to the Cu1-O1-Cu2 plane, and the resulting dihedral angle is $44.2^{\circ}$. The electronic absorption spectrum of 1 in aqueous solution at $\mathrm{pH} 3$ suggests a shift toward trigonal bipyramidal $\mathrm{Cu}(\mathrm{II})$ coordination in solution. Spectral titration of $\mathrm{Na}\left[\mathrm{Cu}_{2}\left(\mathrm{CH}_{3} \mathrm{HXTA}\right)\left(\mathrm{H}_{2} \mathrm{O}\right)_{2}\right]$ with $L$ (where $L=$ pyridine or sodium cyanide) results in complexes with terminal $L$ groups. These exogenous ligands appear to bind in a positive cooperative stepwise fashion. Variable-temperature magnetic susceptibility data for $\mathbf{1}$ indicate that the $\mathrm{Cu}$ (II) ions are antiferromagnetically coupled $\left(-2 J=168 \mathrm{~cm}^{-1}\right)$. X-band EPR spectra of an aqueous solution of 1 shows isotropic signals with $g=2.14$, while a powdered sample of 1 provides no EPR spectrum. A $\Delta M_{s}=2$ transition at $g=\sim 4.5$, expected for weakly magnetically coupled $\mathrm{Cu}(\mathrm{II})$ ions, is not observed for powdered samples but is observed for a methanolic solution sample of $\mathbf{1}$. On the basis of these data, the two $\mathrm{Cu}(\mathrm{II})$ ions are antiferromagnetically coupled in the solid state but due to a coordination geometry change become weakly ferromagnetically or antiferromagnetically coupled in solution. ${ }^{1} \mathrm{H}$ NMR studies on a methanol solution of $\mathbf{1}$ are consistent with weak spin-coupling in solution.

\section{Synopsis}

The dinuclear $\mathrm{Cu}(\mathrm{II})$ complex $\left[\mathrm{Cu}_{2}\left(\mathrm{CH}_{3} \mathrm{HXTA}\right)(\mathrm{Py})_{2}\right]^{-}$-1.5(1,4-dioxane) (1) (where $\mathrm{CH}_{3} \mathrm{HXTA}=\mathrm{N}^{\prime} \mathrm{N}^{\prime}$-(2-hydroxy-5methyl-1,3-xylylene)bis( $N$-(carboxymethyl)glycine; $\mathrm{Py}=$ Pyridine) has been synthesized and characterized by $\mathrm{X}$ ray crystallography, electronic absorption, NMR, and EPR spectroscopies as well as magnetic susceptibility. ${ }^{1} \mathrm{H}$ NMR studies on a methanolic solution of 1 indicate that the two $\mathrm{Cu}(\mathrm{II})$ ions are weakly spin-coupled in solution. The conversion of $\left[\mathrm{Cu}_{2}\left(\mathrm{CH}_{3} \mathrm{HXTA}\right)\left(\mathrm{H}_{2} \mathrm{O}\right)_{2}\right]^{-}(2)$ to 1 is observed upon the addition of pyridine. Complex 2 can also be converted to $\left[\mathrm{Cu}_{2}\left(\mathrm{CH}_{3} \mathrm{HXTA}\right)(\mathrm{CN})_{2}\right]^{3-}(3)$ by the addition of $\mathrm{NaCN}$. In both cases the water ligands of 2 are displaced in a stepwise fashion.

\section{Introduction}

The synthesis and characterization of dinuclear $\mathrm{Cu}(\mathrm{II})$ complexes have received a great deal of attention due to their presence in hemocyanin, tyrosinase, laccase, and ascorbate oxidase. ${ }^{1-5}$ Dinucleating ligands that contain a phenolate donor group have been used extensively to model these dinuclear $\mathrm{Cu}(\mathrm{II})$ metalloprotein active sites. The majority of these complexes contain pyridine, imidazole, benzimidazole, or pyrazole groups as terminal ligands. These complexes serve as excellent models for dicopper(II) centers found in enzymes with histidine-rich coordination environments; however, few systematic investigations of dicopper(II) centers in carboxylate-rich coordination environments have been reported. ${ }^{6}$ This is surprising since many di- and trinuclear metalloprotein active sites have been recognized to have carboxylate-rich coordination environments. ${ }^{7-10}$ The least-explored subclass of these enzymes are the di- and trinuclear metallohydrolases ${ }^{9-11}$ Crystallographically characterized enzymes that fall into this group include phospholipase $C_{,}{ }^{12}$ alkaline phosphatase, ${ }^{13}$ inositol monophosphatase ${ }_{1}^{14}$ DNA polymerase $1,{ }^{15}$ the ribonuclease $\mathrm{H}$ domain of HIV-1 reverse transcriptase ${ }^{16} \mathrm{P} 1$ nuclease, ${ }^{17}$ urease, ${ }^{18}$ the purple acid phosphatases, ${ }^{19-21}$ and the aminopeptidases. ${ }^{22-25}$ These multinuclear hydrolases play critical roles in hydrolyzing some of the most important molecules in life such as DNA, phospholipids, and polypeptides. . $7,8,10,26,27$ They are therefore key players in carcinogenesis, tissue repair, and 
protein degradation processes. Dinuclear metallohydrolases are also involved in the degradation of agricultural neurotoxins as well as several chemical warfare agents. ${ }^{28-30}$

Dinuclear hydrolases utilize as their native metal ions every first-row transition metal ion from $\mathrm{Mn}$ (II) to $\mathrm{Zn}$ (II) plus $\mathrm{Mg}(\mathrm{II})$. The lone metal ion of this group that does not occur natively in any hydrolase is $\mathrm{Cu}(\mathrm{II})$; however, some $\mathrm{Zn}(\mathrm{II})$ enzymes can be reactivated by substitution with $\mathrm{Cu}(\mathrm{II})$ ions. For example, the aminopeptidase from bovine lens (bILAP) can be partially activated by $\mathrm{Cu}(\mathrm{II})$ ions as can alkaline phosphatase. ${ }^{31}$ BILAP has been crystallographically characterized and contains a ( $\mu$-hydroxo)bis( $\mu$-carboxylato)dizinc(II) core with terminal carboxylates at each metal site along with a peptide backbone carbonyl and a lysine amine nitrogen bound to one of the $\mathrm{Zn}$ (II) ions. ${ }^{21,23,24,32,33}$ Crystallographic studies on the aminopeptidase from Aeromonas proteolytica (AAP) revealed a ( $\mu$-aqua)( $\mu$-carboxylato)dizinc(II) core with one terminal carboxylate and one histidine residue at each metal site. ${ }^{25}$ Both $\mathrm{Zn}$ (II) ions in AAP appear to reside in a distorted five coordinate geometry with a Zn-Zn distance of $3.5 \AA$. Remarkably, AAP can be hyperactivated by 6.5 times upon the addition of 2 equiv of $\mathrm{Cu}(\mathrm{II})$ to the apo-enzyme. ${ }^{34,35}$ To our knowledge, this is the only $\mathrm{Zn}$ (II) enzyme that can be hyperactivated by $\mathrm{Cu}(\mathrm{II})$. Since no physical or structural data for the $\mathrm{CU}(\mathrm{II})$ substituted AAP enzyme have been reported to date, structural modifications leading to the hyperactivity of these metal-substituted enzymes are unknown.

In an effort to model the carboxylate-rich coordination environment of the hyperactive dicopper(II) center of AAP, we have synthesized the dinuclear $\mathrm{Cu}(\mathrm{II})$ complex $\mathrm{Na}\left[\mathrm{Cu}_{2}\left(\mathrm{CH}_{3} \mathrm{HXTA}\right)(\mathrm{Py})_{2}\right] \cdot 1.5(1$,4-dioxane) ( $\mathrm{Na}(\mathbf{1})$ ) (where $\mathrm{CH}_{3} \mathrm{HXTA}=N, N^{\prime}$-(2-hydroxy-5-methyl-1,3-xylylene)bis( $N$-(carboxymethyl)glycine). This complex has been characterized by X-ray crystallography, electronic absorption, NMR, and EPR spectroscopies as well as magnetic susceptibility. The reactivity of the previously reported $\mathrm{Na}\left[\mathrm{Cu}_{2}\left(\mathrm{CH}_{3} \mathrm{HXTA}\right)\left(\mathrm{H}_{2} \mathrm{O}\right)_{2}\right]$ complex ${ }^{6}$ with simple anions such as pyridine and cyanide is also discussed.

\section{Experimental Methods}

\section{Synthetic Methods.}

All chemicals were purchased commercially and used as received. $N, N^{\prime}$-(2-hydroxy-5-methyl-1,3-xylylene)bis( $N$ (carboxymethyl)glycine) was synthesized from $p$-cresol, iminodiacetic acid, and formaldehyde according to the method of Schwarzenbach et al. ${ }^{36}$ with minor revisions as reported by Murch et al. ${ }^{37}$ The ligand identity was confirmed by ${ }^{1} \mathrm{H}$ NMR spectroscopy. ${ }^{1} \mathrm{H}$ NMR $\left(\mathrm{D}_{2} \mathrm{O}: \delta 4.70\right): \mathrm{CH}_{3} \mathrm{HXTA}, \delta 2.31(\mathrm{~s}, 3 \mathrm{H}), 3.26(\mathrm{~s}, 8 \mathrm{H}), 3.78(\mathrm{~s}, 4 \mathrm{H})$, $7.06(\mathrm{~s}, 2 \mathrm{H})$. Caution! It has previously been reported that $\mathrm{CH}_{3} \mathrm{HXTA}$ can cause allergic reactions. ${ }^{37}$

The general procedure for the synthesis of dinuclear $\mathrm{Cu}(\mathrm{II})$ complexes of $\mathrm{CH}_{3} \mathrm{HXTA}$ has been previously reported. ${ }^{6}$ For $\mathrm{Na}\left[\mathrm{Cu}_{2}\left(\mathrm{CH}_{3} \mathrm{HXTA}\right)(\mathrm{Py})_{2}\right](\mathrm{Na}(\mathbf{1})), \mathrm{CH}_{3} \mathrm{HXTA}(0.60 \mathrm{~g} ; 1.2 \mathrm{mmol})$ was dissolved in $20 \mathrm{~mL}$ of $\mathrm{H}_{2} \mathrm{O}$. To this solution was added $0.96 \mathrm{~g}$ ( $2.4 \mathrm{mmol})$ of $\mathrm{Cu}$ (II) perchlorate hexahydrate dissolved in $2 \mathrm{~mL}$ of $\mathrm{H}_{2} \mathrm{O}$. The solution immediately turned dark green $(\mathrm{pH} \sim 3.0)$. Acetone was added to this solution causing precipitation of the $\mathrm{Na}\left[\mathrm{Cu}_{2}\left(\mathrm{CH}_{3} \mathrm{HXTA}\right)\left(\mathrm{H}_{2} \mathrm{O}\right)_{2}\right](\mathrm{Na}(2))$ complex. The resulting solid was redissolved in $20 \mathrm{~mL}$ of $\mathrm{MeOH}$, and a 10-fold excess of pyridine was added. Complex 1 was recrystallized by vapor diffusion of 1,4-dioxane into a filtered methanolic solution of $\mathbf{1}$. The analytical purity of $\mathbf{1}$ was checked by elemental analysis (Atlantic Microlab, Inc.). Calcd for $\mathrm{Na}\left[\mathrm{Cu}_{2}\left(\mathrm{CH}_{3} \mathrm{HXTA}\right)(\mathrm{Py})_{2}\right] \cdot 1.5\left(1,4-\right.$ dioxane) (Na(1)) $\left(\mathrm{C}_{33} \mathrm{H}_{39} \mathrm{Cu}_{2} \mathrm{~N}_{4} \mathrm{O}_{12} \mathrm{Na}\right): \mathrm{C}, 47.54 ; \mathrm{H}, 4.72 ; \mathrm{N}, 6.72$. Found: C, 47.19; $\mathrm{H}, 4.80 ; \mathrm{N}, 6.53$.

\section{Crystallographic Studies.}

Green rectangular crystals of 1, suitable for X-ray diffraction studies, were grown by vapor diffusion of 1,4dioxane into a methanolic solution of 1 . A suitable crystal was selected and mounted in a $0.3 \mathrm{~mm}$ diameter X-ray capillary and centered optically on a Seimens P4 diffractometer equipped with an LT-2a low-temperature device that maintained the crystal at $-100^{\circ} \mathrm{C}$ throughout data collection. Autocentering of 25 reflections indicated a 
monoclinic cell. Systematic absences in the data set led to the unambiguous selection of the space group PI. Two standard reflections were measured every 50 reflections and remained constant $( \pm 1 \%)$ throughout the data collection. The copper atoms were located by direct methods, and the remaining non-hydrogen atoms were located by subsequent difference maps and refined anisotropically. Hydrogen atoms were generated in idealized positions with fixed thermal parameters $\left(0.08 \AA^{2}\right)$. A summary of the crystallographic data collection for 1 is presented in Table 1. The complete listings of the crystal data are provided in the Supporting Information.

\section{Table 1. Summary of Crystallographic Data for $\mathrm{Na}\left[\mathrm{Cu}_{2}\left(\mathrm{CH}_{3} \mathrm{HXTA}\right)(\mathrm{Py})_{2}\right] \cdot 1.5(1,4-$ dioxane)}

\begin{tabular}{|l|l|}
\hline empirical formula & $\mathrm{C}_{33} \mathrm{H}_{39} \mathrm{~N}_{4} \mathrm{O}_{13} \mathrm{Cu}_{2} \mathrm{Na}$ \\
\hline $\mathrm{fw}$ & 849.8 \\
\hline cryst system & triclinic \\
\hline space group & $P$ I \\
\hline$a(\AA)$ & $12.550(3)$ \\
\hline$b(\AA)$ & $13.413(3)$ \\
\hline$c(\AA)$ & $13.540(4)$ \\
\hline$\alpha(\mathrm{deg})$ & $117.12(2)$ \\
\hline$\beta(\mathrm{deg})$ & $115.73(2)$ \\
\hline$\gamma(\mathrm{deg})$ & $92.13(2)$ \\
\hline$V\left(\AA^{3}\right)$ & $1747.1(8)$ \\
\hline$Z$ & 2 \\
\hline$\rho_{\text {calc }}\left(\mathrm{g} \mathrm{cm}{ }^{-3}\right)$ & 1.615 \\
\hline$\left.\mu(\mathrm{mm})^{-1}\right)$ & 1.303 \\
\hline radiation & $\mathrm{MoK \alpha}(\lambda=0.71073 \AA)$ \\
\hline temp $\left({ }^{\circ} \mathrm{C}\right)$ & -100 \\
\hline residuals: ${ }^{a} R ; R_{\mathrm{w}}$ & $0.063 ; 0.059$ \\
\hline
\end{tabular}

\section{Physical Methods.}

Electronic absorption spectra were recorded on a Shimadzu UV-3101PC spectrophotometer. Low-temperature dual mode EPR spectroscopy was performed using a Bruker ESP-300E spectrometer equipped with an ER 4116 DM dual mode X-band cavity and an Oxford Instruments ESR-900 helium flow cryostat. All spectra were recorded at a modulation frequency of $100 \mathrm{kHz}$ and modulation amplitude of $1.26 \mathrm{mT}(12.6 \mathrm{G})$ with a sweep rate of $10 \mathrm{mT} \mathrm{s}^{-1}$. EPR spectra were recorded at microwave frequencies of about $9.65 \mathrm{GHz}$ : precise microwave frequencies were recorded for individual spectra to ensure precise $g$-alignment. Other EPR running parameters are specified in the figure legends for individual samples. ${ }^{1} \mathrm{H}$ NMR spectra were recorded in methanol solution on a Bruker ARX-400 spectrometer. Chemical shifts (in ppm) were referenced to the residual protic solvent signal. Elemental analyses were performed by Atlantic Microlabs, Inc. (Norcross, GA). Magnetic susceptibility data were recorded over the temperature range 10-300 K at a measuring field of $2.0 \mathrm{kOe}$ with an SHE Corp. VTS50 SQUID susceptometer interfaced to an IBM 9000 computer system. Calibration and operating procedures have been reported elsewhere. ${ }^{38}$

\section{Results and Discussion}

Enzymes containing dinuclear copper centers play important roles in nature such as the oxidation of organic molecules coupled to the reduction of dioxygen, reduction of nitrogen oxides, dioxygen transport, and hydrolysis chemistry. ${ }^{3,4}$ Consequently, the characterization of their structure and function is a problem of outstanding importance. A fundamental and, as yet, largely unexplored issue is the determination of the structural and magnetic properties of dinuclear copper(II) centers in carboxylate-rich coordination 
sites. ${ }^{6}$ Carboxylate ligands provide Lewis acidities markedly different from those of the more common nitrogenbased ligands which, in turn, will alter the reactivity of the metal centers. Therefore, the synthesis and structural characterization of dinuclear metal complexes with carboxylate-rich coordination environments will provide insight into the physical properties of dinuclear metalloenzymes with similar coordination environments.

\section{Structural Studies.}

X-ray diffraction studies were carried out on $\mathrm{Na}\left[\mathrm{Cu}_{2}\left(\mathrm{CH}_{3} \mathrm{HXTA}\right)(\mathrm{Py})_{2}\right] \cdot 1.5(1,4$-dioxane) $(\mathrm{Na}(\mathbf{1}))$. Compound 1 crystallizes in the space group PI. Two $\left[\mathrm{Cu}_{2}\left(\mathrm{CH}_{3} \mathrm{HXTA}\right)(\mathrm{Py})_{2}\right]^{-}$complexes are found in the unit cell along with two sodium ions and one and one-half 1,4-dioxane molecules that form an intricate bonding network. Hydrogen bonds are formed between the lattice water molecules and the carboxylate carbonyl oxygen atoms. The bound carboxylate oxygen $\mathrm{O} 2$ forms a hydrogen bond with a lattice water molecule resulting in the longest $\mathrm{Cu}-\mathrm{O}$ carboxylate bond distance $(1.985(4) \AA)$. In addition, the sodium atoms present in the unit cell are five coordinate with a distorted trigonal bipyramidal coordination geometry. $\mathrm{Na}(\mathbf{1})$ is bound by four carboxylate oxygen atoms and a 1,4-dioxane oxygen atom. Two of the carboxylate and a 1,4-dioxane oxygen atom make up the equatorial plane while the remaining two carboxylate oxygen atoms are in the axial positions. All of the $\mathrm{Na}(\mathrm{I})$ bond distances are between 2.287 and $2.403 \AA$, which is typical for sodium-oxygen bond distances.

A thermal ellipsoid drawing of the anion of 1 with a partial labeling scheme is shown in Figure 1 . Selected bond distances and angles are collected in Table 2. Each $\mathrm{Cu}(\mathrm{II})$ ion in $\mathbf{1}$ is bound by two carboxylate oxygen atoms, one amine nitrogen atom, the phenolate oxygen atom, and one pyridine nitrogen atom. Four of the five $\mathrm{Cu}(\mathrm{II})$-ligand bond lengths for each $\mathrm{Cu}(\mathrm{II})$ ion in 1 are nearly equal (1.945-2.027 $\AA$ ) while one bond length for each $\mathrm{Cu}(\mathrm{II})$ ion is significantly longer (2.132 and $2.129 \AA$, respectively) suggesting these bonds are in the axial position of a square pyramid. The Cu1-O1 ( $\mu$-phenoxo oxygen) bond is 2.005(4) Å while the Cu2-O1 bond is 1.999(3) $\AA$ indicating that the oxygen of the bridging phenolate is equatorial for both $\mathrm{Cu} 1$ and $\mathrm{Cu} 2$. The Cu1-O1-Cu2 angle is $123.7^{\circ}$ while the phenyl ring of the $\mathrm{CH}_{3} \mathrm{HXTA}$ ligand is twisted relative to the $\mathrm{Cu} 1-\mathrm{O} 1-\mathrm{Cu} 2$ plane, and the resulting dihedral angle is $44.2^{\circ}$. Using the method of Muetterties and Guggenberger, ${ }^{39}$ the geometry of each $\mathrm{Cu}(\mathrm{II})$ center was determined. The shape-determining dihedral angle $e_{3}$ for a tetragonal pyramid is $0.0^{\circ}$ whereas a trigonal bipyramid has an $e_{3}$ angle of $53.1^{\circ}$. For 1 , the dihedral angle $e_{3}$ for Cu1 is $7.4^{\circ}$ whereas for Cu2 it is $6.1^{\circ}$. On the basis of these data, the $\mathrm{Cu}(\mathrm{II})$ centers in $\mathbf{1}$ exhibit slightly distorted square pyramidal geometries.

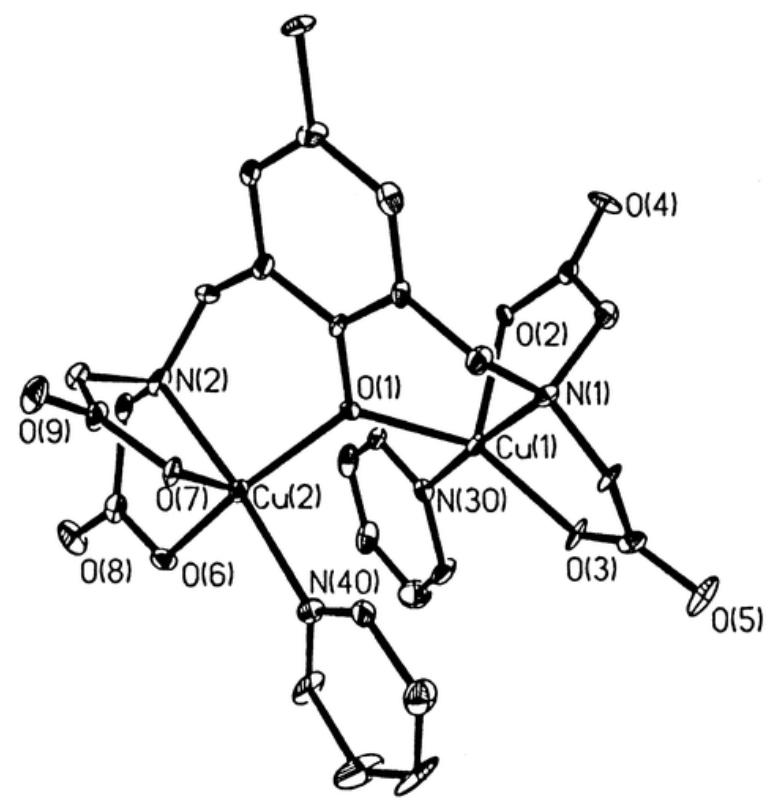

Figure 1 ORTEP drawing of the $\left[\mathrm{Cu}_{2}\left(\mathrm{CH}_{3} \mathrm{HXTA}\right)(\mathrm{Py})_{2}\right]^{-}$anion showing a partial numbering scheme (carbon and hydrogen atoms are not labeled for clarity). 
Table 2. Selected Bond Lengths $(\AA)$ and Bond Angles (deg) for $\mathrm{Na}\left[\mathrm{Cu}_{2}\left(\mathrm{CH}_{3} \mathrm{HXTA}\right)(\mathrm{Py})_{2}\right] \cdot 1.5(1,4-\mathrm{dioxane})^{a}$

\begin{tabular}{|c|c|c|c|}
\hline \multicolumn{4}{|l|}{ Bond Lengths } \\
\hline Cu1-01 & $2.005(7)$ & $\mathrm{Cu} 2-06$ & \begin{tabular}{|l}
$1.956(9)$ \\
\end{tabular} \\
\hline Cu2-01 & $1.999(9)$ & Cu2-O7 & $2.129(6)$ \\
\hline Cu1-N1 & $2.018(8)$ & Cu1-N30 & $1.999(9)$ \\
\hline $\mathrm{Cu} 2-\mathrm{N} 2$ & $2.027(8)$ & Cu2-N40 & $2.006(9)$ \\
\hline Cu1-O2 & $2.132(8)$ & Cu1‥Cu2 & $3.531(6)$ \\
\hline Cu1-O3 & $1.945(7)$ & & \\
\hline $\mathrm{Na1-O4}$ & $2.317(11)$ & $\mathrm{Na1-05A}$ & $2.367(6)$ \\
\hline $\mathrm{Na1-08A}$ & $2.403(6)$ & Na1-09A & $2.287(9)$ \\
\hline $\mathrm{Na1-080}$ & $2.355(10)$ & & \\
\hline \multicolumn{4}{|l|}{ Bond Angles } \\
\hline N1-Cu1-O1 & $94.6(3)$ & N2-Cu2-O1 & $93.7(4)$ \\
\hline N1-Cu1-O2 & $83.4(3)$ & $\mathrm{N} 2-\mathrm{Cu} 2-\mathrm{O} 6$ & $84.4(4)$ \\
\hline O1-Cu1-O2 & $95.1(3)$ & O1-Cu2-O6 & $150.0(2)$ \\
\hline N1-Cu1-O3 & $84.0(3)$ & N2-Cu2-O7 & $83.8(3)$ \\
\hline O1-Cu1-O3 & $149.8(3)$ & O1-Cu2-O7 & $94.9(3)$ \\
\hline O2-Cu1-O3 & $114.5(3)$ & O6-Cu2-O7 & $114.5(3)$ \\
\hline N1-Cu1-N30 & $174.0(4)$ & $\mathrm{N} 2-\mathrm{Cu} 2-\mathrm{N} 40$ & $175.2(4)$ \\
\hline O1-Cu1-N30 & $91.0(3)$ & $\mathrm{O} 1-\mathrm{Cu} 2-\mathrm{N} 40$ & $91.0(4)$ \\
\hline O2-Cu1-N30 & $94.3(3)$ & O6-Cu2-N40 & $91.7(4)$ \\
\hline O3-Cu1-N30 & $92.0(3)$ & O7-Cu2-N40 & $95.3(3)$ \\
\hline Cu1-01-Cu2 & $123.7(4)$ & & \\
\hline O4-Na1-080 & $95.4(3)$ & O4-Na1-O5A & $95.2(3)$ \\
\hline O80-Na1-O5A & $82.6(3)$ & O4-Na1-08A & $88.6(3)$ \\
\hline O80-Na1-O8A & $93.3(3)$ & O5A-Na1-08A & $174.7(4)$ \\
\hline 04-Na1-09A & $137.0(4)$ & O80-Na1-O9A & $127.3(4)$ \\
\hline O5A-Na1-09A & $87.3(3)$ & O8A-Na1-09A & $92.4(3)$ \\
\hline
\end{tabular}

${ }^{a}$ For labels, see the ORTEP drawing.

The $\mathrm{Cu}$--Cu separation in $\mathbf{1}$ is $3.531 \AA$. This $\mathrm{Cu}$--Cu separation is the shortest of the four known related singly bridged dicopper(II) complexes. ${ }^{6,40-42}\left[\mathrm{Cu}_{2}(\mathrm{BBIP})\left(\mathrm{H}_{2} \mathrm{O}\right)_{2}\right]^{3+}$ (where $\mathrm{BBIP}=2,6-$ bis[(bis(benzimidazolylmethyl)amino)methyl]-p-cresol) has a $\mathrm{Cu}$--Cu separation of 3.875 $\AA$, $\left[\mathrm{Cu}_{2}(\mathrm{BIMP})\left(\mathrm{CH}_{3} \mathrm{OH}\right)_{2}\right]^{3+}$ (where BIMP = 2,6-bis[((bis(1-methylimidazol-2-yl)methyl)amino)methyl]-4methylphenol) has a Cu--Cu separation of $4.090 \AA$, $\left[\mathrm{Cu}_{2}\left(\mathrm{BPMP} \mathrm{Cl}_{2}\right]^{+}\right.$(where BPMP = 2,6-bis[[bis $(2-$ pyridylmethyl)amino]methyl]-4-methylphenol) has a $\mathrm{Cu}$--Cu separation of $4.128 \AA$, and $\left[\mathrm{Cu}_{2}\left(\mathrm{CH}_{3} \mathrm{HXTA}\right)\left(\mathrm{H}_{2} \mathrm{O}\right)_{2}\right]^{-}(2)$ has a $\mathrm{Cu}$--Cu separation of $3.726 \AA$. The large $\mathrm{Cu}$-- $\mathrm{Cu}$ separations for $\left[\mathrm{Cu}_{2}(\mathrm{BBIP})\left(\mathrm{H}_{2} \mathrm{O}\right)_{2}\right]^{3+},\left[\mathrm{Cu}_{2}(\mathrm{BIMP})\left(\mathrm{CH}_{3} \mathrm{OH}\right)_{2}\right]^{3+}$, and $\left[\mathrm{Cu}_{2}(\mathrm{BPMP}) \mathrm{Cl}_{2}\right]^{+}$have been attributed to steric repulsions between the benzimidazole, imidazole, or pyridyl groups, respectively, as well as the formation of two adjacent five-membered rings. ${ }^{40-42}$ For $\left[\mathrm{Cu}_{2}\left(\mathrm{CH}_{3} \mathrm{HXTA}\right)\left(\mathrm{H}_{2} \mathrm{O}\right)_{2}\right]^{-}$steric interactions between the terminal carboxylate groups are minimal, so a subtle combination of long $\mathrm{Cu}-\mathrm{N}$ amine distances compared to the average equatorial $\mathrm{Cu}-\mathrm{O}$ carboxylate distance ( 2.020 vs 1.965 ) and the formation of two adjacent five membered rings results in the large $\mathrm{Cu}-\mathrm{Cu}$ separation. ${ }^{6}$ For $\mathbf{1}$, the $\mathrm{Cu}$--Cu separation is decreased relative to $\mathbf{2}$ because the apical bond of the square pyramid is directed toward two carboxylate oxygen atoms rather than the bridging phenolate oxygen atom. This results in a decrease in the $\mathrm{Cu} 1-\mathrm{O} 1$ and $\mathrm{Cu} 2-\mathrm{O} 2$ bond lengths providing a more acute $\mathrm{Cu} 1-\mathrm{O} 1-\mathrm{Cu} 2$ bond angle 
for 1 compared to 2. Cu--Cu separations for doubly bridged complexes utilizing the 2,6-bis(methylamino)-pcresol group are typically in the range $2.9-3.3 \AA .^{3}$

\section{Electronic Absorption Spectra.}

The visible electronic absorption spectra of $\mathbf{1}$ and $\mathbf{2}$ in aqueous solution at pH 3.0 are shown in Figure 2 . All of the complexes studied exhibited absorptions in the $200-350 \mathrm{~nm}$ range that can be attributed to ligand absorption bands and amine- or carboxylate-to-copper ligand-to-metal charge-transfer bands (LMCT). 6,37,42-44

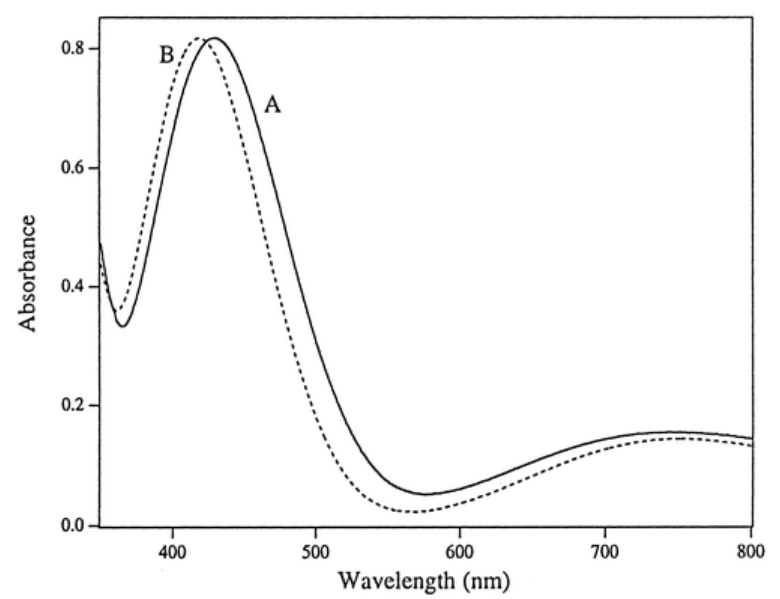

Figure 2 Visible electronic absorption spectra of $(\mathrm{A})\left[\mathrm{Cu}_{2}\left(\mathrm{CH}_{3} \mathrm{HXTA}\right)\left(\mathrm{H}_{2} \mathrm{O}\right)_{2}\right]^{-}$and $(\mathrm{B})\left[\mathrm{Cu}_{2}\left(\mathrm{CH}_{3} \mathrm{HXTA}\right)(\mathrm{Py})_{2}\right]^{-}$.

Compound 1 exhibits an absorption band at $435 \mathrm{~nm}\left(\varepsilon=0.71 \mathrm{mM}^{-1} \mathrm{~cm}^{-1}\right)$ that is assigned to a phenoxo-tocopper LMCT band. Similar absorptions were observed for several related ( $\mu$-phenoxo)dicopper(II) complexes and were definitively assigned by substitution of the para-methyl group of $p$-cresol with electron-withdrawing or -donating groups. ${ }^{3,6}$ The visible absorption spectrum of 1 also contains a band at $750 \mathrm{~nm}\left(\varepsilon=0.15 \mathrm{mM}^{-1} \mathrm{~cm}^{-1}\right)$ (Figure 2). This band is characteristic of $\mathrm{Cu}(\mathrm{II}) \mathrm{d}-\mathrm{d}$ transitions. The position of this band suggests that the geometry about the $\mathrm{Cu}(\mathrm{II})$ ions is best described as trigonal bipyramidal. ${ }^{45}$ This is in contrast to X-ray data that clearly indicate that each $\mathrm{Cu}(\mathrm{II})$ ion resides in a distorted square pyramidal environment. To determine the geometry of the $\mathrm{Cu}(\mathrm{II})$ ions in solution, a direct comparison of the energies of the ligand field transitions in both the solution and solid states is required. A solid-state (Nujol mull) electronic absorption spectrum of 1 was recorded (Figure 3). Two transitions are observed at 430 and $650 \mathrm{~nm}$ that correspond to the phenoxo-to- $\mathrm{Cu}(\mathrm{II})$ LMCT band and the $\mathrm{Cu}(\mathrm{II}) \mathrm{d}-\mathrm{d}$ band, respectively. The position of the $\mathrm{d}-\mathrm{d}$ band for $\mathbf{1}$ in the solid state is indicative of a square pyramidal geometry for $\mathrm{Cu}(\mathrm{II})$. Thus, the distorted square pyramidal geometry observed for $\mathbf{1}$ in the solid state is not maintained in solution. This geometrical change may be a result of the relaxation of the twisted phenol ring relative to the Cu1-01-Cu2 plane. 


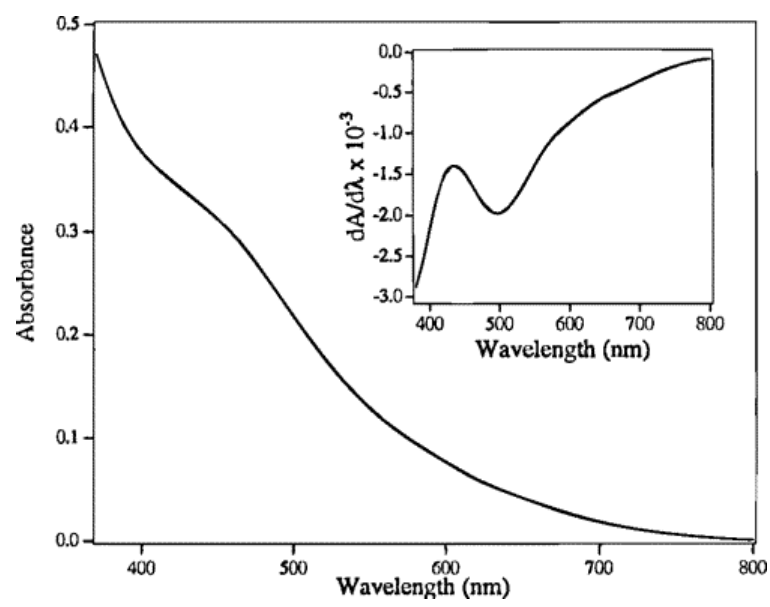

Figure 3 Solid-state (Nujol mull) electronic absorption spectrum of $\left[\mathrm{Cu}_{2}\left(\mathrm{CH}_{3} \mathrm{HXTA}\right)(\mathrm{Py})_{2}\right]^{-}$. Inset: First derivative spectrum.

To determine if the water ligands of $\mathbf{2}$ could be replaced by neutral or anionic ligands, we tested the binding of the monodentate ligands pyridine and cyanide to $\mathbf{2}$. Spectral titration of $\mathbf{2}$ with pyridine causes a shift in the LMCT band from 420 to $435 \mathrm{~nm}$. These data suggest that $\mathbf{2}$ can be converted to 1 by the addition of pyridine. A plot of the absorbance maximum between 420 and $435 \mathrm{~nm}\left(\Delta \lambda_{\max }\right)$ vs equivalents of pyridine added reveals a sigmodial binding curve (Figure 4). The position of the absorption band at $750 \mathrm{~nm}$ for $\mathbf{2}$ assigned to the copper $d-d$ band does not change over the course of the titration. The lack of an isosbestic point indicates that the reaction of 2 to 1 does not involve the discreet intermediate $\left[\mathrm{Cu}_{2}\left(\mathrm{CH}_{3} \mathrm{HXTA}\right)(\mathrm{Py})\left(\mathrm{H}_{2} \mathrm{O}\right)\right]$. Similarly, titration of 2 with an aqueous solution of sodium cyanide does not alter the position of the $d$ - $d$ band at $750 \mathrm{~nm}$ but shifts the LMCT band from 420 to $455 \mathrm{~nm}$. A plot of the absorbance maximum between 420 and $455 \mathrm{~nm}\left(\Delta \lambda_{\max }\right)$ vs equivalents of cyanide added also reveals a sigmodial binding curve (Figure 5) similar to that observed for the addition of pyridine to $\mathbf{2}$. These data indicate that $\mathbf{2}$ can also be converted to the dicyano dicopper(II) $\mathrm{CH}_{3} \mathrm{HXTA}$ complex $\left[\mathrm{Cu}_{2}\left(\mathrm{CH}_{3} \mathrm{HXTA}\right)(\mathrm{CN})_{2}\right]^{3-}(3)$ by the addition of sodium cyanide.

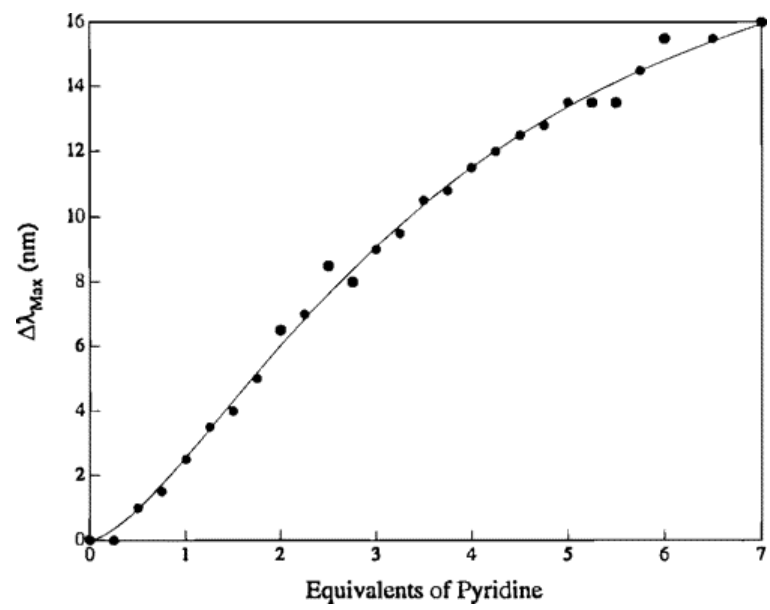

Figure 4 Plot of the absorbance maximum between 420 and $435 \mathrm{~nm}\left(\Delta \lambda_{\max }\right)$ vs equivalents of pyridine added to $\left[\mathrm{Cu}_{2}\left(\mathrm{CH}_{3} \mathrm{HXTA}\right)\left(\mathrm{H}_{2} \mathrm{O}\right)_{2}\right]^{-}\left(1.0 \times 10^{-3} \mathrm{M}\right)$ in methanolic solution. 


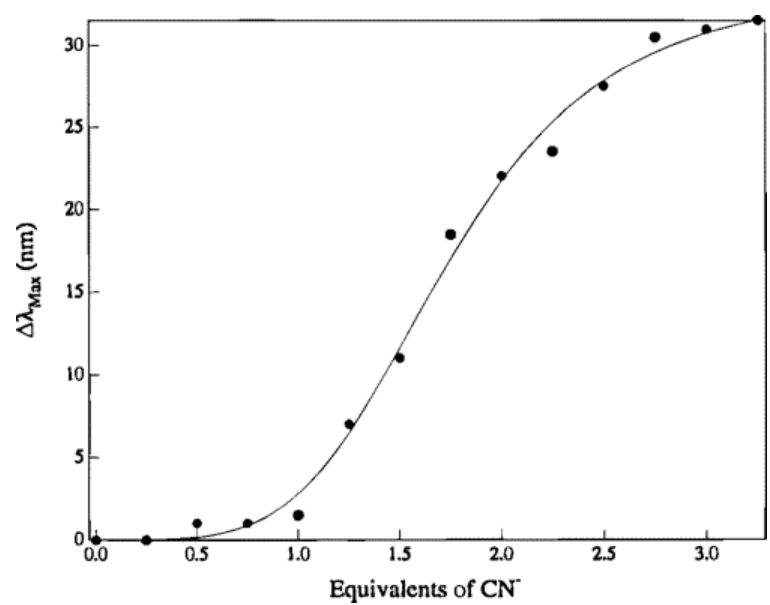

Figure 5 Plot of the absorbance maximum between 420 and $455 \mathrm{~nm}\left(\Delta \lambda_{\max }\right)$ vs equivalents of sodium cyanide added to $\left[\mathrm{Cu}_{2}\left(\mathrm{CH}_{3} \mathrm{HXTA}\right)\left(\mathrm{H}_{2} \mathrm{O}\right)_{2}\right]^{-}\left(1.0 \times 10^{-3} \mathrm{M}\right)$ in methanolic solution.

The sigmodial nature of the titration curves of $\mathbf{2}$ with pyridine or cyanide is indicative of a cooperative stepwise addition of exogenous ligands to $\mathbf{2}$; that is, the binding of one pyridine, for example, affects the binding of the second pyridine molecule (Scheme 1). ${ }^{46}$ Assuming infinite cooperativity, that is $\mathbf{2}$ either has all or none of the exogenous ligands bound, the following equilibrium can be written:

\section{$\left[\mathrm{Cu}_{2}\left(\mathrm{CH}_{3} \mathrm{HXTA}\right)\left(\mathrm{H}_{2} \mathrm{O}\right)_{2}\right]^{-}+n \mathrm{X} \leftrightarrow\left[\mathrm{Cu}_{2}\left(\mathrm{CH}_{3} \mathrm{HXTA}\right)(\mathrm{X})_{2}\right]^{-}$}

(1)

Here $\mathrm{X}$ is either pyridine or cyanide and $n$ is the number of small molecule binding sites. ${ }^{46}$ Since infinite cooperativity is not physically possible, $n$ is typically an indicator of the degree of cooperativity (i.e. $n>1$ represents positive cooperativity). Solving for the fractional dissociation constants provides eq 2 ,

$$
Y=\frac{[\mathrm{L}]^{n}}{\alpha K_{1} K_{2}+[\mathrm{L}]^{n}}
$$

(2)

where $K_{1}$ and $K_{2}$ are the individual dissociation constants for $L$ and $\alpha$ is a constant. Fitting the data in Figure 4 to eq 2 provides values for $K_{1}$ and $K_{2}$ that are 15.2 and $5.8 \mathrm{mM}$, respectively, with an $n$ value of 1.5. These data indicate that pyridine binds to 2 very weakly and in a positive cooperative fashion. Similarly, cyanide binds to 2 very weakly $\left(K_{1}=33.7 \mathrm{mM}, K_{2}=10.9 \mathrm{mM}\right)$ and in a positive cooperative fashion $(n=4.1)$. These data indicate that pyridine binds more tightly to 2 than does cyanide, which is consistent with the fact that it would be more difficult to add a negatively charged ligand to the $\mathrm{Cu}$ (II) centers in $\mathbf{2}$ since they are already in a highly negatively charged environment. The positive cooperativity in ligand binding for $\mathbf{2}$ is likely the result of the phenoxo-linking group since this moiety is flexible and can twist relative to the Cu1-01-Cu2 plane upon ligand binding altering the Cu1-01-Cu2 angle. This may also perturb the oxygen of the bridging phenolate changing its binding mode from axial to equatorial for one or both $\mathrm{Cu}(\mathrm{II})$ ions. 

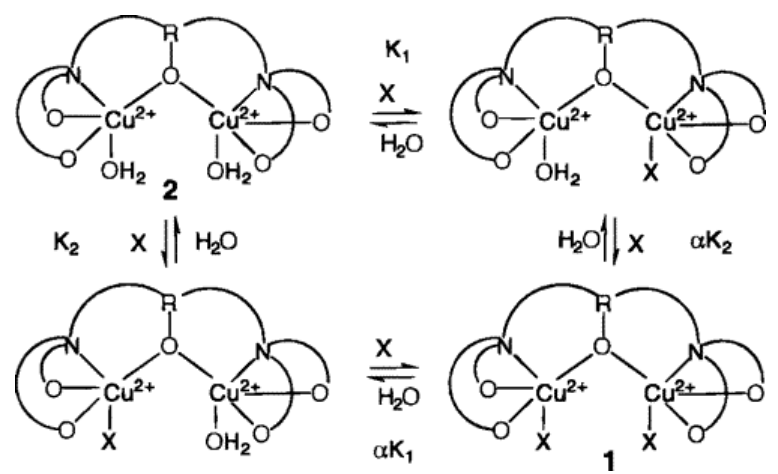

Scheme 1

\section{Magnetic Properties.}

No X-band EPR signals could be observed on a powdered sample of 1 at either $77 \mathrm{~K}$ or room temperature. These data are indicative of strong coupling between the two copper centers in the solid state. Variable-temperature magnetic susceptibility data for 1 were collected over the temperature range 10-300 K. The shape of the $\chi_{\mathrm{m}}$ vs $T$ plot for 1 shows a maximum at $150 \mathrm{~K}$ indicative of antiferromagnetically coupled $\mathrm{Cu}(\mathrm{II})$ centers. Simulation of the data using a spin-exchange Hamiltonian, $H=-2 J S_{1} \cdot S_{2}$, where $S_{1}=S_{2}=1 / 2$ gives $-2 J=168 \mathrm{~cm}^{-}$ ${ }^{1}$ consistent with the lack of an observable EPR signal for a solid sample of $\mathbf{1}$. The exchange coupling in $\mathbf{1}$ is due to the fact that the $\mu$-phenoxo oxygen bond is equatorial to both $\mathrm{Cu} 2$ and $\mathrm{Cu} 1$. In dinuclear square pyramidal $\mathrm{Cu}$ (II) complexes of this type, the unpaired electron resides in the $\mathrm{d}_{x 2-y 2}$ orbital. ${ }^{42,43,47}$ This coordination mode provides significant orbital overlap between the magnetic orbital $d_{x 2-y 2}$ of Cu2 with the magnetic orbital $d_{x 2-y 2}$ of Cu1 so exchange coupling occurs.

The solution spectrum of 1 at room temperature (Figure 6) displays an isotropic signal with $g=2.128$ and $A=$ $6.87 \mathrm{mT}$. Lowering the temperature to $77 \mathrm{~K}$ provided an essentially axial EPR signal which was simulated using an $S=1 / 2$ spin Hamiltonian, and the resulting fit provided $g_{x}, g_{y}$, and $g_{z}$ values of 2.097, 2.116, and 2.323, respectively, and an $A_{z}\left({ }^{63} \mathrm{Cu}\right)=16.2 \mathrm{mT}$ (Figure 6). The X-band EPR spectra of a methanolic solution of 1 at $77 \mathrm{~K}$ also reveals a $\Delta M_{s}=2$ transition at $g=4.5$ (Figure 7). The temperature dependence of all of the observed signals between 4 and $70 \mathrm{~K}$ exhibited Curie law behavior. These data suggest that the two $\mathrm{Cu}(\mathrm{II})$ ions in $\mathbf{1}$ are either weakly ferromagnetically or antiferromagnetically coupled in solution, similar to met-hemocyanin. ${ }^{48}$ Computer simulation of the $g \sim 2$ signal does not match the experimental spectrum exactly in that the intensities of some features are not reproduced accurately, even though the resonance positions are precisely duplicated. There are two phenomena that likely account for this. The first is the presence of an underlying $\Delta M_{s}=2$ transition that is predicted from the observation of its high-field partner (note the very broad absorption centered at $4250 \mathrm{G}$ ) (Figure 6). The second phenomenon is that, in conjunction with the $\Delta M_{s}=2$ transition, off-axis extrema will occur in the EPR spectrum and lead to increased EPR absorption at field values other than those at which the principal $g$-values occur. However, double integration of the $g \sim 2$ signal reveals that this signal accounts for only $\sim 3 \%$ of the spins in the sample. 


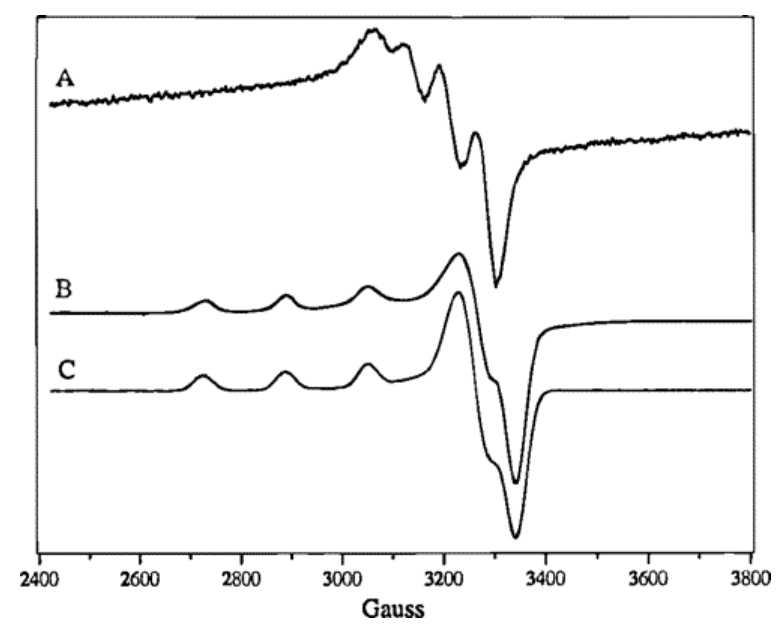

Figure 6 X-band EPR spectra: (A) a methanolic solution of $\left[\mathrm{Cu}_{2}\left(\mathrm{CH}_{3} \mathrm{HXTA}\right)(\mathrm{Py})_{2}\right]^{-}$at $298 \mathrm{~K},(\mathrm{~B})$ a frozen methanolic solution of $\left[\mathrm{Cu}_{2}\left(\mathrm{CH}_{3} \mathrm{HXTA}\right)(\mathrm{Py})_{2}\right]^{-}$at $77 \mathrm{~K}$; (C) simulation of (B) with $g_{x}, g_{y}$, and $g_{z}$ values of 2.097, 2.116, and 2.323, respectively, and an $A_{z}\left({ }^{63} \mathrm{Cu}\right)=16.2 \mathrm{mT}$. Both spectra were recorded with $2 \mathrm{~mW}$ microwave power, $1.26 \mathrm{mT}$ field modulation amplitude, $100 \mathrm{kHz}$ modulation frequency, and $12 \mathrm{mT} \mathrm{s}^{-1}$ field sweep rate.

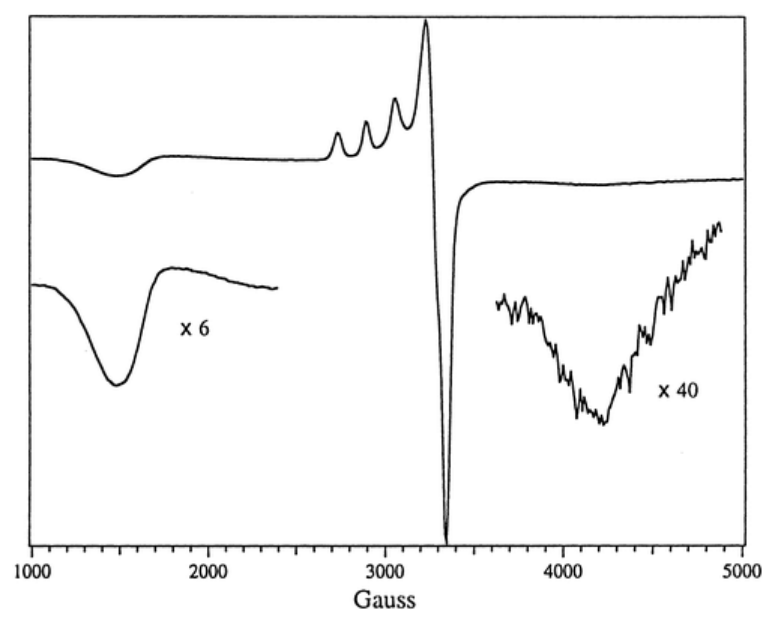

Figure $7 \mathrm{X}$-band EPR spectrum of a frozen methanolic solution of $\left[\mathrm{Cu}_{2}\left(\mathrm{CH}_{3} \mathrm{HXTA}\right)(\mathrm{Py})_{2}\right]^{-}$at $77 \mathrm{~K}$ with a microwave power of $2.0 \mathrm{~mW}$, a modulation amplitude $1.26 \mathrm{mT}$, a modulation frequency of $100 \mathrm{kHz}$, and a $5 \mathrm{mT} \mathrm{s}^{-1}$ field sweep rate.

\section{${ }^{1} \mathrm{H}$ NMR Spectroscopy.}

${ }^{1} \mathrm{H}$ NMR is a natural technique to probe paramagnetic systems since only protons proximate to the paramagnetic center are affected. ${ }^{49-51}$ Building on our initial success using NMR spectroscopy to probe dinuclear $\mathrm{Cu}(\mathrm{II})$ complexes, ${ }^{6,52-55}$ we have probed the structural and magnetic properties of $\mathbf{1}$ in methanolic solution. Spincoupled $\mathrm{Cu}(\mathrm{II})$ centers provide relatively sharp hyperfine shifted ${ }^{1} \mathrm{H}$ NMR signals since they possess a diamagnetic $(S=0)$ ground state. ${ }^{56}$ Complex 1 exhibits several sharp, hyperfine shifted ${ }^{1} \mathrm{H}$ NMR signals in methanol solution at $300 \mathrm{~K}$ in the $120-0 \mathrm{ppm}$ chemical shift range (Figure 8 , Table 3 ). ${ }^{52}$ Several of the hyperfine shifted ${ }^{1} \mathrm{H}$ NMR signals observed for 1 can be initially assigned by inspection of their peak areas. Signals $D(28$ ppm), $E(14.0 \mathrm{ppm}), \mathrm{F}(13.1 \mathrm{ppm})$, and $\mathrm{G}(11.5 \mathrm{ppm})$ integrate to 4:2:2:3 protons, respectively (Table 3$)$. These data, taken together with the crystallographic results, suggest that signals $E$ or $F$ and $G$ arise from meta-phenol and the para-methylphenol protons, respectively. 


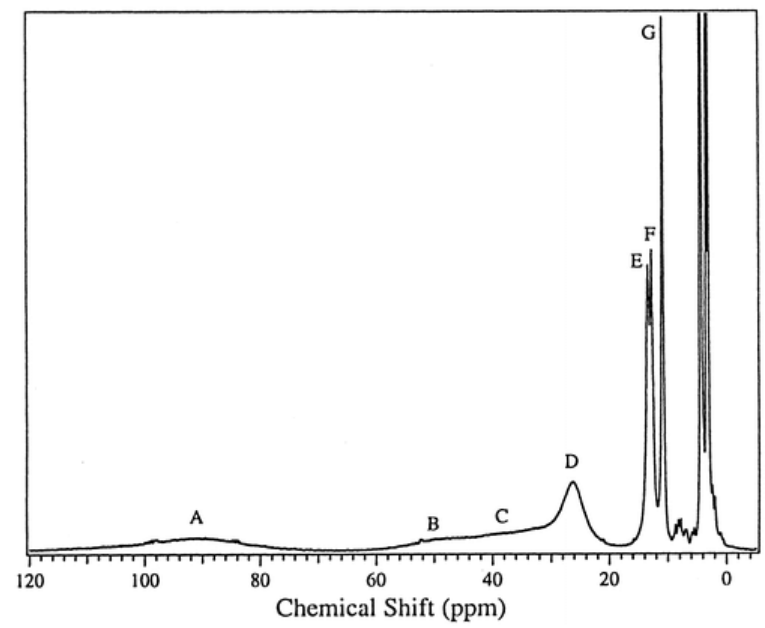

Figure $8400 \mathrm{MHz}{ }^{1} \mathrm{H}$ NMR spectrum of $\left[\mathrm{Cu}_{2}\left(\mathrm{CH}_{3} \mathrm{HXTA}\right)(\mathrm{Py})_{2}\right]^{-}$in $\mathrm{MeOD}$ at $298 \mathrm{~K}$.

Table 3. Properties of the Observed Hyperfine-Shifted ${ }^{1} \mathrm{H} N M R$ Resonances of $\mathrm{Na}\left[\mathrm{Cu}_{2}\left(\mathrm{CH}_{3} \mathrm{HXTA}\right)(\mathrm{Py})_{2}\right] \cdot 1.5(1,4-$ dioxane)

\begin{tabular}{|l|l|l|l|l|l|}
\hline signal & assgnt & chem shift $(\mathrm{ppm})^{a}$ & line width & \\
& $(\mathrm{Hz})$ & rel area $^{c}$ & $T_{1}^{d}(\mathrm{~ms})$ \\
\hline $\mathrm{A}$ & $\mathrm{NCH}_{2} \mathrm{CO}_{2}$ & 95 & 10000 & $\mathrm{ND}^{e}$ & $>1$ \\
\hline $\mathrm{B}$ & $\mathrm{NCH}_{2} \mathrm{CO}_{2}$ & 48 & $\sim 3500$ & $\mathrm{ND}^{e}$ & $>1$ \\
\hline $\mathrm{C}$ & $\mathrm{Py} \alpha-H$ & 38 & $\mathrm{ND}^{e}$ & $\mathrm{ND}^{e}$ & $>1$ \\
\hline $\mathrm{D}$ & $\mathrm{Py} \beta-H$ & 28 & 2000 & 4 & $>1$ \\
\hline $\mathrm{E}$ & $\mathrm{Ph} \beta-H$ & 14.0 & 250 & 2 & 2 \\
\hline $\mathrm{F}$ & $\mathrm{Py}-H$ & 13.1 & 230 & 2 & 3 \\
\hline $\mathrm{G}$ & $\mathrm{PhCH}_{3}$ & 11.5 & 140 & 3 & 2 \\
\hline
\end{tabular}

${ }^{a}$ All chemical shifts are in ppm relative to the residual solvent signal at $3.4 \mathrm{ppm}$ for $\mathrm{H}_{3} \mathrm{COH}^{.}{ }^{b}$ Full width at halfmaximum. ${ }^{c}$ Relative areas are based on the area of signals $\mathrm{H} .{ }^{d} T_{1}$ values were obtained at $400 \mathrm{MHz}$ and 35 ${ }^{\circ} \mathrm{C} .{ }^{e}$ Not determined.

Definitive assignment of the para-methylphenol protons comes from selective replacement of the para-methyl group of 1 with $\mathrm{Cl}$ which causes signal $\mathrm{G}$ to disappear. Assignment of signals $\mathrm{C}, \mathrm{D}$, and $\mathrm{F}$ to the pyridine $\alpha-\mathrm{H}, \beta-\mathrm{H}$, and $\mathrm{y}-\mathrm{H}$ protons comes from replacement of the pyridine ligands with cyanide which causes these signals to disappear. Assignment of the remaining three signals comes from $T_{1}$ values and comparison of the spectrum of 1 with that of two related complexes, 2 and $\left[\mathrm{Cu}_{2}\left(\mathrm{CH}_{3} \mathrm{HXTA}\right)(\mathrm{OH})\right]^{2-}(\mathbf{4}) \cdot{ }^{6}$ The ${ }^{1} \mathrm{H}$ NMR spectrum of 4 shows five hyperfine shifted signals at $60^{\circ} \mathrm{C}$ in $\mathrm{D}_{2} \mathrm{O}$ solution, $\mathrm{pH} 10$, and the assignment of each of the observed hyperfine shifted signals has been previously reported. ${ }^{6}$ Comparison of the chemical shift, $T_{1}$ values, and relative integrations of signals $C(83 \mathrm{ppm})$ and $C^{\prime}(65 \mathrm{ppm})$ of complex 4 (both of which were assigned to the diastereotopic methylene- $\mathrm{CH}_{2}$ acetate protons) with signals $\mathrm{A}(95 \mathrm{ppm})$ and $\mathrm{B}$ (48 ppm) of $\mathbf{1}$ is consistent with the assignment of these signals to the diastereotopic methylene- $\mathrm{CH}_{2}$ protons of the acetate arm. By default, signal $\mathrm{E}$ is assigned to the meta-phenol protons.

Antiferromagnetically coupled dicopper(II) centers have a singlet $(S=0)$ ground state and a triplet $(S=1)$ first excited state that differ in energy by the exchange constant, $J .{ }^{56}$ That hyperfine shifted signals are observed for these systems is due to the proximity of the diamagnetic ground state and the first excited state. Since the population distribution between these two levels is dependent upon the temperature as well as the magnitude of $J,{ }^{57}$ it follows that the temperature dependence of the hyperfine-shifted ${ }^{1} \mathrm{H}$ NMR signals should correlate with the magnitude of the spin-coupling interaction between the two $\mathrm{Cu}(\mathrm{II})$ ions. Curie (contact shift decreases with increasing temperature) or anti-Curie (contact shift increases with increasing temperature) behavior has been 
previously shown to depend on the magnitude of $J$. The temperature dependence of the hyperfine shifted signals of 1 were recorded over the temperature range $0-70{ }^{\circ} \mathrm{C}$ in methanol solution (Figure 9). All but one of the hyperfine shifted signals sharpen and shift toward the diamagnetic region as the temperature is increased following the Curie law. Signal $\mathrm{C}$ sharpens and shifts away from the diamagnetic region with increasing temperature since it is one of the $\beta-\mathrm{CH}_{2}$ protons of the carboxylate arms which undergo temperature-dependent proton exchange mechanisms. These data indicate that the two $\mathrm{Cu}(\mathrm{II})$ ions in $\mathbf{1}$ are either weakly ferromagnetically or antiferromagnetically coupled consistent with the EPR data.

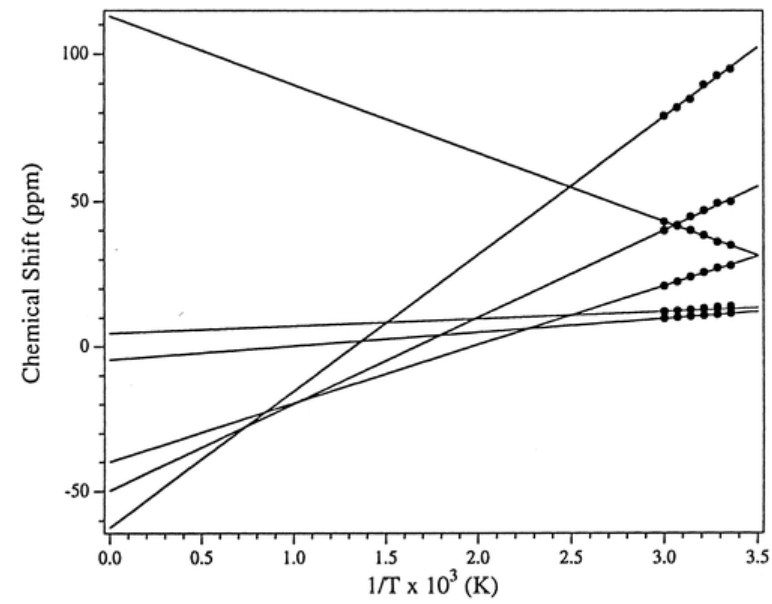

Figure 9 Temperature dependence of the hyperfine-shifted ${ }^{1} \mathrm{H}$ NMR resonances of $\left[\mathrm{Cu}_{2}\left(\mathrm{CH}_{3} \mathrm{HXTA}\right)(\mathrm{Py})_{2}\right]^{-}$in $\mathrm{MeOD}$ between 298 and $333 \mathrm{~K}$.

In conclusion, we have synthesized a new dicopper(II) complex containing a $\mu$-phenoxo bridging ligand with terminal carboxylate oxygen, amine nitrogen, and pyridine ligands and have characterized this complex by X-ray crystallography, electronic absorption, NMR, and EPR spectroscopies as well as magnetic susceptibility. On the basis of these data, the two $\mathrm{Cu}(\mathrm{II})$ ions are moderately antiferromagnetically coupled in the solid states, but due to a coordination geometry change, become either weakly ferromagnetically or antiferromagnetically coupled in solution. ${ }^{1} \mathrm{H}$ NMR studies on a methanol solution of $\mathbf{1}$ also indicate that the two $\mathrm{Cu}(\mathrm{II})$ ions are weakly spincoupled in solution. At the present time, we have not observed any phosphatase or esterase activity toward common $p$-nitrophenol substrates by 1 . However, the conversion of $\left[\mathrm{Cu}_{2}\left(\mathrm{CH}_{3} \mathrm{HXTA}\right)\left(\mathrm{H}_{2} \mathrm{O}\right)_{2}\right]^{-}$to 1 is observed upon the addition of pyridine. Complex 2 can also be converted to $\left[\mathrm{Cu}_{2}\left(\mathrm{CH}_{3} \mathrm{HXTA}\right)(\mathrm{CN})_{2}\right]^{3-}(3)$ by the addition of $\mathrm{NaCN}$. In both cases, the water ligands of $\mathbf{2}$ are displaced in a stepwise fashion. The stepwise binding of exogenous ligands to $\mathbf{2}$ mimics the first step in catalysis by AAP in that it was recently established that substrate binds only to the first metal binding site in AAP and not the second. ${ }^{58-60}$ While no spectroscopic or structural data are available for the $\mathrm{Cu}(\mathrm{II})$-substituted AAP or bILAP enzymes, the structural and magnetic properties of the complexes reported herein may provide insight into the structural properties of the active dicopper(II) centers in AAP and bILAP. We are currently probing the structural and magnetic properties of the hyperactive dicopper(II) AAP enzyme.

\section{Supporting Information Available}

A crystal packing diagram and tables detailing the $\mathrm{X}$-ray data collection and refinement, bond distances, bond angles, final anisotropic thermal parameters, calculated or refined $\mathrm{H}$ atom coordinates, and atomic coordinates and equivalent isotropic thermal parameters (9 pages). Ordering information is given on any current masthead page. 


\section{Terms \& Conditions}

Electronic Supporting Information files are available without a subscription to ACS Web Editions. The American Chemical Society holds a copyright ownership interest in any copyrightable Supporting Information. Files available from the ACS website may be downloaded for personal use only. Users are not otherwise permitted to reproduce, republish, redistribute, or sell any Supporting Information from the ACS website, either in whole or in part, in either machine-readable form or any other form without permission from the American Chemical Society. For permission to reproduce, republish and redistribute this material, requesters must process their own requests via the RightsLink permission system. Information about how to use the RightsLink permission system can be found at http://pubs.acs.org/page/copyright/permissions.html.

\section{Acknowledgment}

This work was supported by the National Science Foundation (Grant CHE-9422098; R.C.H.). The Bruker ARX-400 NMR spectrometer and the Bruker ESP-300E EPR spectrometer were purchased with funds provided by the National Science Foundation (Grants CHE-9311730 and BIR-9413530, respectively) and Utah State University. The authors are also grateful to Professor John L. Hubbard for his assistance in the crystal structure determination and to Professor Charles J. O'Connor for recording the variable-temperature magnetic susceptibility data. We also acknowledge the NSF for partial funding of the X-ray diffractometer (Grant CHE9002379).

\section{References}

1 Kitajima, N.; Moro-oka, Y. Chem. Rev. (Washington, D.C.)1994, 94, 737-757.

2 Solomon, E. I.; Tuczek, F.; Root, D. E.; Brown, C. A. Chem. Rev. (Washington, D.C.)1994, 94, 827-856.

3 Sorrell, T. N. Tetrahedron 1989, 45, 3-68.

4 Karlin, K. D.; Tyeklar, Z. Bioinorganic Chemistry of Copper; Chapman \& Hall: New York, 1993.

5 Karlin, K. D.; Wei, N.; Jung, B.; Kaderli, S.; Niklaus, P.; Zuberbühler, A. D. J. Am. Chem. Soc.1993, 115, 9506-9514.

6 Holz, R. C.; Brink, J. M.; Gobena, F. T.; O'Connor, C. J. Inorg. Chem.1994, 33, 6086-6092.

7 Feig, A. L.; Lippard, S. J. Chem. Rev. (Washington, D.C.)1994, 94, 759-805.

8 Fenton, D. E.; Okawa, H. J. Chem. Soc., Dalton Trans. 1993, 1349-1357.

9 Vallee, B. L.; Auld, D. S. Proc. Natl. Acad. Sci. U.S.A.1993, 90, 2715-2718.

10 Vallee, B. L.; Auld, D. S. Biochemistry1993, 32, 3-6500.

11 Wilcox, D. E. Chem. Rev. (Washington, D.C.)1996, 96, 2435-2458.

12 Hough, E.; Hansen, L. K.; Birknes, B.; Jynge, K.; Hansen, S.; Horvik, A.; Little, C.; Dodson, E.; Derewenda, Z. Nature 1989, 338, 357-360.

13 Kim, E. E.; Wyckoff, H. W. J. Mol. Biol. 1991, 218, 449-464.

14 Bone, R.; Frank, L.; Springer, J. P.; Pollack, S. J.; Osborne, S.-A.; Atack, J. R.; Knowles, M. R.; McAllister, G.; Ragan, C. I.; Broughton, H. B.; Baker, R.; Fletcher, S. R. Biochemistry1994, 33, 9460-9467.

15 Beese, L. S.; Steitz, T. A. EMBO J. 1991, 10, 25-33.

16 Davies, J. F.; Hostomska, Z.; Hostomsky, Z.; Jordan, S. R.; Mathews, D. A. Science 1991, 252, 88-95.

17 Lahm, A.; Volbeda, A.; Suck, D. J. Mol. Biol. 1990, 215, 207-210.

18 Jabri, E.; Carr, M. B.; Hausinger, R. P.; Karplus, P. A. Science 1995, 268, 998-1004.

19 Holz, R. C.; Que, L., Jr.; Ming, L.-J. J. Am. Chem. Soc.1992, 114, 4434-4436.

20 True, A. E.; Scarrow, R. C.; Randall, C. R.; Holz, R. C.; Que, L. J. J. Am. Chem. Soc.1993, 115, 4246-4255.

21 Sträter, N.; Klabunde, T.; Tucker, P.; Witzel, H.; Krebs, B. Science 1995, 268, 1489-1492.

22 Roderick, S. L.; Matthews, B. W. Biochemistry1993, 32, 3907-3912.

23 Burley, S. K.; David, P. R.; Taylor, A.; Lipscomb, W. N. Proc. Natl. Acd. Sci. U.S.A. 1990, 87, 6878-6882.

24 Burley, S. K.; David, P. R.; Sweet, R. M.; Taylor, A.; Lipscomb, W. N. J. Mol. Biol. 1992, 224, 113-140.

25 Chevrier, B.; Schalk, C.; D'Orchymont, H.; Rondeau, J.-M.; Moras, D.; Tarnus, C. Structure 1994, 2, 283-291. 
26 Karlin, K. D. Science 1993, 261, 701-708.

27 Que, L., Jr.; True, A. E. Dinuclear iron- and manganese-oxo sites in biology; John Wiley \& Sons, Inc.: New York, 1990; Vol. 38, pp 97-200.

28 Chin, J. Acc. Chem. Res.1991, 24, 145-152.

29 Lai, K.; Dave, K. I.; Wild, J. R. J. Biol. Chem. 1994, 269, 16579-16584.

30 Menger, F. M.; Gan, L. H.; Johnson, E.; Durst, D. H. J. Am. Chem. Soc.1987, 109, 2800-2803.

31 Allen, M. P.; Yamada, A. H.; Carpenter, F. H. Biochemistry1983, 22, 3778-3783.

32 Sträter, N.; Lipscomb, W. N. Biochemisty 1995, 34, 9200-9210.

33 Sträter, N.; Lipscomb, W. N. Biochemisty 1995, 34, 14792-14800.

34 Prescott, J. M.; Wagner, F. W.; Holmquist, B.; Vallee, B. L. Biochem. Biophys. Res. Commun. 1983, 114, 646-652.

35 Prescott, J. M.; Wagner, F. W.; Holmquist, B.; Vallee, B. L. Biochemistry1985, 24, 5350-5356.

36 Schwarzenbach, G.; Anderegg, G.; Sallmann, R. Helv. Chim. Acta 1952, 35, 1785-1792.

37 Murch, B. P.; Bradley, F. C.; Boyle, P. D.; Papaefthymiou, V.; Que, L., Jr. J. Am. Chem. Soc.1987, 109, 7993-8003.

38 O'Connor, C. J. Prog. Inorg. Chem. 1982, 29, 203-283.

39 Muetterties, E. L.; Guggenberger, L. J. J. Am. Chem. Soc.1974, 96, 1748-1756.

40 Nishida, Y.; Takeuchi, M.; Oishi, N.; Kida, S. Inorg. Chim. Acta 1985, 96, 81-85.

41 Berends, H. P.; Stephan, D. W. Inorg. Chim. Acta 1985, 99, L53-L56.

42 Oberhausen, K. J.; Richardson, J. F.; Buchanan, R. M.; McCusker, J. K.; Hendrickson, D. N.; Latour, J.-M. Inorg. Chem.1991, 30, 1357-1365.

43 Berends, H. P.; Stephan, D. W. Inorg. Chem.1987, 26, 749-754.

44 Solomon, E. I.; Baldwin, M. J.; Lowery, M. D. Chem. Rev. (Washington, D.C.)1992, 92, 521-542.

45 Hathaway, B. J.; Billing, D. E. Coord. Chem. Rev. 1970, 5, 143-207.

46 Segel, I. H. Enzyme Kinetics: Behavior and analysis of rapid equilibrium and steady-state enzyme systems, 1st ed.; John Wiley \& Sons: New York, 1975; p 204.

47 Nishida, Y.; Shimo, H.; Maehara, H.; Kida, S. J. Chem. Soc., Dalton Trans. 1985, 1945-1951.

48 Wilcox, D. E.; Long, J. R.; Solomon, E. I. J. Am. Chem. Soc.1984, 106, 2186-2194.

49 Bertini, I.; Luchinat, C. NMR of Paramagnetic Molecules in Biological Systems; Benjamin \& Cummings: Menlo Park, CA, 1986.

50 Bertini, I.; Turano, P.; Vila, A. J. Chem. Rev. (Washington, D.C.)1993, 93, 2833-2932.

51 NMR Methodology for Paramagnetic Proteins; La Mar, G. N., de Ropp, J. S., Eds.; Plenum Press: New York, 1993; Vol. 12, pp 1-78.

52 Holz, R. C.; Brink, J. M. Inorg. Chem.1994, 33, 4609-4610.

53 Holz, R. C.; Brink, J. M.; Rose, R. R. J. Magn. Reson. A 1996, 119, 125-128.

54 Holz, R. C.; Gobena, F. T. Polyhedron 1996, 15, 2179-2185.

55 Brink, J. M.; Rose, R. R.; Holz, R. C. Inorg. Chem.1996, 35, 2878-2885.

56 Byers, W.; Williams, R. J. P. J. Chem. Soc., Dalton Trans. 1972, 555-560.

57 Drago, R. S. Physical Methods for Chemists, 2nd ed.; Saunders: Orlando, FL, 1992.

58 Bennett, B.; Holz, R. C. J. Am. Chem. Soc.1997, 119, 1923-1933.

59 Chen, G.; Edwards, T.; D'souza, V. M.; Holz, R. C. Biochemistry1997, 36, 4278-4286.

60 Bennett, B.; Holz, R. C. Biochemistry1997, 36, 9837-9846. 